\title{
ESTIMATION OF GENETIC PARAMETERS FOR MILK YIELD IN THE FIRST THREE LACTATIONS OF HOLSTEIN COWS USING RANDOM REGRESSION MODEL
}

\author{
Neivein Gamal ${ }^{1}$, Manal Elsayed ${ }^{2}$ and Salah Galal ${ }^{2}$ \\ 1- Scientific Computation Unit, Faculty of Agriculture, Ain Shams University, \\ Shoubra El-Khaima, Cairo, Egypt, 2- Animal Production Department, Faculty of \\ Agriculture, Ain Shams University, Shoubra El-Khaima, Cairo, Egypt
}

\section{SUMMARY}

Data used in the study were collected from the Assiout private farm in Assiout Governorate in the south of Egypt. In total, a data set of 8473 test-day milk yield (TDMY) records for the first three lactations (3875, 2993 and 1605 records, respectively)of 414 cows daughters of more than 66 sires and 197 dams was available covering the period from 1998 till 2004. Data were classified according to the month of calving into four seasons, winter, spring, summer and autumn. The statistical model included year-season, the linear and quadratic regression orders on age, fixed regression, a random additive genetic effect for each animal, a random permanent environmental effect for each cow and a random residual effect. The Incomplete Gamma Function (IGF) was chosen to describe the shape of the lactation curve. This function was fitted for each lactation for each cow. DFREML software was used to estimate the components of (co)variance of TDMY in a Random Regression Model (RRM). Estimates of the additive genetic correlations between TDMYs ranged form -0.978 to 0.993 , -0.730 to 0.992 and -0.086 to 0.991 for the three lactations, respectively. Estimates of heritability of TDMY increased from 0.030 for days in milk (DIM) 65 to 0.142 for DIM 185 then decreased to 0.035 for DIM 275 in the first lactation. Heritability increased from 0.154 for DIM 65 to 0.215 for DIM 155 then decreased to 0.180 for DIM 215 in the second lactation. Heritability decreased from 0.486 for DIM 5 to 0.409 for DIM 125 then increased to 0.696 for DIM 305 in the third lactation. Results indicated that IGF was suitable to describe the lactation curve of Holstein cattle in the first three lactations under the conditions of the present study.

Keywords: Random regression model, Incomplete Gamma Function, genetic parameters, Test-day milk yield, lactation curve, Holstein

\section{INTRODUCTION}

Many factors affect milk production of the cow from one test-day (TD) to the next. It is difficult to model for whole 305-day yields taking into account all such factors (Jamrozik et al., 1996). A test-day model for genetic evaluation can account for these factors such as, day of the year (including weather conditions), management groups within a herd, and, for each cow, days in milk (DIM), pregnancy status and number of milkings daily (Meyer et al., 1989 and Ptak \& Schaeffer, 1993). Test-day

Issued by The Egyptian Society of Animal Production 
model (TDM) can, also, account for the effect of test date, number of records, interval between records and order of test-day records (Reents and Dopp, 1996). Moreover, models using longitudinal measurements would include information about the pattern of a lactation curve for a cow (Schaeffer and Dekkers, 1994).

Many models have been described for the analysis of test-day yields by several studies (Wood, 1967, Ali and Schaeffer, 1987 and Wilmink, 1987). Random regression model (RRM) has become a popular choice for the analysis of longitudinal data or repeated records. This analysis is challenging because it requires numerous parameters ((co)variances between random regression (RR) coefficients) and measurement of error variances (Meyer, 2002), in addition to the (co)variance structure of the test-day yields (Liu et al., 2000).

The objective of this study was to estimate genetic parameters of test day milk yields (TDM's) in the first three lactations in single trait model with a small data set from a private Holstein dairy farm using random regression with the covariance function technique.

\section{MATERIAL AND METHODS}

\section{Data}

Data used in this study were collected from the Assiout private farm in Assiout Governorate in the south of Egypt. Most of records used in the study were taken from 210 Holstein heifers that had been imported from Germany in year 1998 as heifersin-calf and F1 daughters. In total, a data set of 8473 test-day milk yield (TDMY) records of 415 Holstein cows daughters of more and than $66^{1}$ sires 197 dams was available from 1998 till 2004. These data represent 892 lactations where test-day (TD) records were taken from day 5 until day 305. All records after 305 day were excluded. Data were classified according to the month of calving into four seasons, winter (from 21 December to 20 March), spring (from 21 March to 20 June), summer (from 21 June to 20 September) and autumn (from 21 September to 20 December). The average of TDMY in the three lactations was $11.43 \mathrm{~kg}$ with standard deviation $5.76 \mathrm{~kg}$. Data structure is given in Table 1.

\section{Management}

Animals were kept in open yards. Each twenty five cows were joined with a bull for mating. Cows were fed corn silage in summer and alfalfa in winter. Concentrates were provided at a daily rate of $5.5 \mathrm{~kg} /$ dry cow, $7.5 \mathrm{~kg}$ for freshening non-milked cow and $4 \mathrm{~kg}$ for maintenance requirement and $1 \mathrm{~kg}$ for each $2 \mathrm{~kg}$ milk produced for milking cows. Cows were machine-milked twice a day and the amount of milk was automatically recorded.

\section{Statistical analysis}

Model. The model for the three studied lactations in matrix notation was assumed as follows:

$\mathbf{Y}=\mathbf{X b}+\mathbf{Z a}+\mathbf{W} \mathbf{p}+\mathbf{e}$,

where,

\footnotetext{
1 some of the animals had unknown sires
} 
Y: the TDMY vector; b: the fixed effect of year-season, the fixed regression coefficients of TDMY on DIM and the fixed regression coefficients of TDMY on age vector; a: the random regression coefficients vector; p: the random permanent environmental effects vector of cows; $\mathbf{X}, \mathbf{Z}$, and $\mathbf{W}$ : the covariables and incidence matrices; and e: the random residual effects vector.

Random effects ( $a, p$ and e) are assumed to be normally distributed with mean 0 and variance $\mathrm{V}$ as follows

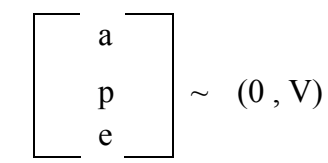

where,

$\mathrm{V}=\operatorname{Var}\left[\begin{array}{l}\mathrm{a} \\ \mathrm{p} \\ \mathrm{e}\end{array}\right]=\left[\begin{array}{lll}\mathrm{G} \otimes \mathrm{A} & 0 & 0 \\ 0 & \mathrm{I} P & 0 \\ 0 & 0 & \mathrm{R}\end{array}\right]$

And, $G=\operatorname{Var}\left(\begin{array}{lll}\alpha_{j 0} & \alpha_{j 1} & \alpha_{j 2}\end{array}\right)^{\prime}$, according to Jamrozik et al. (1997)

where,

G: the matrix of additive genetic covariance between RR coefficients, assumed to be homogenous for all animals, while the $\alpha_{\mathbf{j m}}$ : random regression coefficients $(\mathrm{m})$, of TDMY on DIM; P: the covariance matrix of the permanent environmental effect; I: is the identity matrix; A: the matrix of additive genetic numerator relationship between the animals; $\otimes$ : the Kronecker product function (direct product) (Searle, 1966); and R: a diagonal matrix with elements that depend on DIM.

Table 1. Structure of the raw data in the first three lactations

\begin{tabular}{llll}
\hline & \multicolumn{3}{c}{ Lactation } \\
\cline { 2 - 4 } & First & Second & Third \\
\hline Number of TD ${ }^{1}$ milk records & 3875 & 2993 & 1605 \\
Number of cows & 414 & 283 & 188 \\
Number of dams & 197 & 136 & 89 \\
Number of known sires & 66 & 58 & 50 \\
Number of year-seasons & 24 & 23 & 19 \\
Average age of cows at calving, mo & 29 & 42 & 57 \\
Mean of TDMY ${ }^{2}$, kg & 10.41 & 12.41 & 11.48 \\
Phenotypic range of TDMY, kg & $0.2-34$ & $0.2-40$ & $0.2-33$ \\
Standard deviation of TDMY, kg & 5.1 & 6 & 6.2 \\
Coefficient of variation of TDMY \% & 48.15 & 48.36 & 52.31 \\
\hline
\end{tabular}

${ }^{1}$ Test-day (TD), ${ }^{2}$ Test-day milk yield (TDMY)

where, $\mathrm{R}$ is estimated for each group of DIM, where each lactation is divided into ten periods within each of them the residual variance matrix is constant for all DIM. So that $\mathrm{R}$ has 10 different values on the diagonal. Residual variance was assumed to be constant for each subclass $(\mathrm{k})$ within lactation. The covariance between residuals in 
TD records on different DIM records was assumed zero in the single trait models for both within and between cows.

Fitting the curve. Orders of Legendere, Ali and Schaeffer function and Incomplete Gamma function were tried to describe the lactation curve. Among these functions the only one that met the conditions of the present data and gave full results was the Incomplete Gamma function (IGF) which was fitted for each lactation for each cow. According to Wood (1967) this function is:

Where,

$$
\mathrm{Y}_{\mathrm{t}}=\mathrm{a}_{0} \mathrm{t}^{\mathrm{a} 1} \exp ^{\mathrm{a} 2 \mathrm{t}}
$$

$\mathrm{Y}_{\mathrm{t}}$ : TDMY at time $\mathrm{t}$; exp: refers to the natural exponential function; $\mathrm{a}_{0}$ : the initial MY; $a_{1}$ : the ascent to peak; $a_{2}$ : the descent from peak; and $a_{0}, a_{1}$ and $a_{2}$ are constants for a given lactation

So, the linear function of the three covariates that describe TDMY at $t$ time is:

$$
\ln Y_{t}=\ln a_{0}+a_{1} \ln t+a_{2} t
$$

This submodel, i.e. Wood's function is to illustrate the main features of RR coefficients of TDMY at $t$ time with the three parameters $\left(a_{0}, a_{1}\right.$ and $\left.a_{2}\right)$ to be estimated. Now the submodel can be detailed for fitting the lactation curve as

$\operatorname{Ln} Y_{i j k l}=\left[\ln \mu_{0}+\mu_{1} \times(\ln \mathrm{c})+\mu_{2} \times(\mathrm{c})\right]+\left[\ln \mathrm{a}_{0 \mathrm{j}}+\mathrm{a}_{1 \mathrm{j}} \times(\ln \mathrm{c})+\mathrm{a}_{2 \mathrm{j}} \times(\mathrm{c})\right]$

$+\left[\ln \mathrm{p}_{0 \mathrm{j}}+\mathrm{p}_{1 \mathrm{j}} \times(\ln \mathrm{c})+\mathrm{p}_{2 \mathrm{j}} \times(\mathrm{c})\right]+\left[\ln \mathrm{e}_{0 \mathrm{j}}+\mathrm{e}_{1 \mathrm{j}} \times(\ln \mathrm{c})+\mathrm{e}_{2 \mathrm{j}} \times(\mathrm{c})\right]+\varepsilon_{\mathrm{ijkl}}$,

where the first part in this equation represents the fixed regression; the second part represents RR of the animal additive genetic effects; the third part represents RR of the cow permanent environmental effects; the fourth part represents residual regression of a DIM ; and the fifth part represents error term.

Procedure of analysis. DFREML software package (Meyer, 1998a) was used to estimate the components of variance and covariance. Starting value was obtained from the results of Alnajjar (2001).

\section{RESULTS AND DISCUSSION}

\section{Additive genetic and permanent environmental (co)variance estimates for coefficients of IGF}

Estimates of additive genetic and permanent environmental (co)variances for coefficients a's of IGF in the first three lactations are presented in Table 2. Additive genetic variances for the natural logarithm of the initial milk yield $\left(\ln \mathrm{a}_{0}\right)$ were $0.0233,0.3363$ and 0.3914 for the three lactations, respectively. Additive genetic variances for the rate of ascent to peak $\left(\mathrm{a}_{1}\right)$ of lactation were $0.0136,0.0518$ and 0.2420 for the three lactations, respectively. Additive genetic variances for the rate of descent from peak $\left(\mathrm{a}_{2}\right)$ of lactation were $0.0211,0.00001$ and 0.0001 for the three lactations, respectively.

The additive genetic variance for $\mathrm{a}_{0}$ and $\mathrm{a}_{1}$ increased with advance in lactation. The additive genetic variance for $a_{2}$ decreased sharply from first lactation to second lactation but increased slightly from second lactation to third lactation. In the first lactation, the additive genetic covariance between the coefficients, with the highest magnitude, was that negative between $\mathrm{a}_{0}$ and $\mathrm{a}_{2}$, i.e. the higher the initial yield the slower the descent. In the second and third lactations, the additive genetic covariance 
between the coefficients with the highest magnitude was that negative between $\mathrm{a}_{0}$ and $a_{1}$, i.e. the higher the initial yield the slower the ascent. Permanent environmental variances for the natural logarithm of the initial milk yield $\left(\ln \mathrm{ep}_{0}\right)$ were 0.2327 , 1.2699 and 1.1622 for the three lactations, respectively. Permanent environmental variances for the rate of ascent to peak $\left(\mathrm{ep}_{1}\right)$ of lactation were $0.0813,0.1502$ and 0.4578 for the three lactations, respectively. Permanent environmental variances for the rate of descent from peak $\left(\mathrm{ep}_{2}\right)$ of lactation were $0.0229,0.00003$ and 0.0001 for the three lactations, respectively. The permanent environmental variance for $\mathrm{ep}_{0}$ increased from first lactation to second lactation but decreased from second lactation to third lactation. The permanent environmental variance for $\mathrm{ep}_{1}$ increased with advance in lactation. The permanent environmental variance for $\mathrm{ep}_{2}$ decreased from first lactation to second lactation but increased from second lactation to third lactation. The covariance estimates of permanent environmental were very low for the three lactations.

Table 2. Estimates of additive genetic and permanent environmental (co) variances in the first three lactations for coefficients (a's) of IGF, kg

\begin{tabular}{|c|c|c|c|c|c|c|c|}
\hline \multicolumn{4}{|c|}{ Additive genetic } & & \multicolumn{3}{|c|}{ Permanent environmental } \\
\hline & $\ln \mathbf{a}_{0}{ }^{1}$ & $\mathbf{a}_{1}^{2}$ & $\mathbf{a}_{2}{ }^{3}$ & & $\ln \mathbf{e p}_{0}^{4}$ & $\mathrm{ep}_{1}{ }^{5}$ & $\mathbf{e p}_{2}{ }^{6}$ \\
\hline \multicolumn{8}{|c|}{ First lactation } \\
\hline $\ln \mathrm{a}_{0}$ & 0.0233 & & & $\ln \mathrm{ep}_{0}$ & 0.2327 & & \\
\hline$a_{1}$ & 0.0074 & 0.0136 & & $\mathrm{ep}_{1}$ & 0.0133 & 0.0813 & \\
\hline$a_{2}$ & -0.0218 & -0.0065 & 0.0211 & $\mathrm{ep}_{2}$ & 0.0094 & 0.0166 & 0.0229 \\
\hline \multicolumn{8}{|c|}{ Second lactation } \\
\hline $\ln \mathrm{a}_{0}$ & 0.3363 & & & $\ln \mathrm{ep}_{0}$ & 1.2699 & & \\
\hline$a_{1}$ & -0.1310 & 0.0518 & & $\mathrm{ep}_{1}$ & -0.4100 & 0.1502 & \\
\hline $\mathrm{a}_{2}$ & 0.0015 & -0.0006 & 0.00001 & $\mathrm{ep}_{2}$ & 0.0046 & -0.0019 & 0.00003 \\
\hline \multicolumn{8}{|c|}{ Third lactation } \\
\hline $\ln \mathrm{a}_{0}$ & 0.3914 & & & $\ln \mathrm{ep}_{0}$ & 1.1622 & & \\
\hline$a_{1}$ & -0.1268 & 0.2420 & & $\mathrm{ep}_{1}$ & -0.5552 & 0.4578 & \\
\hline $\mathrm{a}_{2}$ & -0.0002 & .0 .0036 & 0.0001 & $\mathrm{ep}_{2}$ & 0.0035 & -0.0050 & 0.0001 \\
\hline
\end{tabular}

${ }_{2}^{1} \ln \mathrm{a}_{0}$ : natural logarithmic of estimate of additive genetic effect of the initial milk yield

${ }^{2} a_{1}$ : estimate of additive genetic effect of the ascent to peak

${ }^{3} a_{2}$ : estimate of additive genetic effect of from peak

${ }^{4} \ln \mathrm{ep}_{0}$ : natural logarithmic of the permanent environmental effect of the initial milk yields

${ }^{5} \mathrm{ep}_{1}$ : the permanent environmental effect of the ascent to peak

${ }^{6} \mathrm{ep}_{2}$ : the permanent environmental effect of the descent from peak.

Variances of $\ln \mathrm{a}_{0}$ and $\mathrm{ep}_{0}$ are lower than those reported by Alnajjar (2001) in the three lactations. Low variance could be due to lesser pedigree information. The much lower additive genetic variances of the lactation curve $\mathrm{a}_{0}, \mathrm{a}_{1}$ and $\mathrm{a}_{2}$ relative to their permanent environmental variances indicate that in this set of data the environment plays, by far, the dominant influence on the lactation curve. 
Additive genetic and permanent environmental eigenvalues

The three eigenvalues for the additive genetic and permanent environmental covariances for TDMY in the first three lactations are presented in Table 3. The first eigenvalues for the additive genetic effects accounted for $80.99 \%, 99.83 \%$ and $73.22 \%$ of the total additive genetic variance in the three lactations, respectively. The first eigenvalues for the permanent environmental effects accounted for $69.58 \%$, 98.87 and $90.58 \%$ of the total permanent environmental variance in the three lactations, respectively. The estimates of the first eigenvalue in the three lactations indicated that most genetic variation is expressed in the beginning of lactation. Genetic eigenvalues estimated in this study are small as compared to the environmental indicating that changing the shape of lactation curve is more likely to be through environment than genetics. Pool and Meuwissen (2000) used 4 and 5 eigenvalues for the additive and permanent environmental effects. They noted that eginvalues for permanent environment were lower than those of the additive ones. The first retained three additive genetic eigenvectors (factors) absorbed the genetic variances in the coefficients a's of IGF. Each factor has an egeinvalue that corresponds to the amount of additive genetic variance explained by that factor from the total additive genetic variance, each a combination of the observed test-day milk yields. These three derived traits could be named as the initial milk yield, the rate of ascent to peak and the rate of descent from peak.

Table 3. Eigenvalues for the additive genetic and permanent environmental covariances for TDMY in the three lactations

\begin{tabular}{|c|c|c|c|c|c|c|}
\hline & \multicolumn{2}{|c|}{ Eigenvalues } & \multicolumn{2}{|c|}{$\begin{array}{l}\text { Proportion of total } \\
\text { variance }(\%)\end{array}$} & \multicolumn{2}{|c|}{$\begin{array}{l}\text { Cumulative } \\
\text { proportion of total } \\
\text { variance }(\%)\end{array}$} \\
\hline & additive & permanent & additive & permanent & additive & permanent \\
\hline \multicolumn{7}{|c|}{ First lactation } \\
\hline Factor $1^{1}$ & 0.046953 & 0.234380 & 80.99046 & 69.58113 & 80.99 & 69.58 \\
\hline Factor $2^{1}$ & 0.010678 & 0.084122 & 18.41941 & 24.97368 & 99.41 & 94.55 \\
\hline Factor $3^{1}$ & 0.000342 & 0.018342 & 0.590129 & 5.445188 & 100.00 & 100.00 \\
\hline \multicolumn{7}{|c|}{ Second Lactation } \\
\hline Factor 1 & 0.387445 & 1.403990 & 99.82830 & 98.865647 & 99.83 & 98.86 \\
\hline Factor 2 & 0.000665 & 0.016105 & 0.171293 & 1.134090 & 99.99 & 99.99 \\
\hline Factor 3 & 0.000002 & 0.000004 & 0.000408 & 0.000263 & 100.00 & 100.00 \\
\hline \multicolumn{7}{|c|}{ Third lactation } \\
\hline Factor 1 & 0.463853 & 1.467570 & 73.22117 & 90.58309 & 73.22 & 90.58 \\
\hline Factor 2 & 0.169620 & 0.152566 & 26.77524 & 9.416859 & 99.99 & 99.99 \\
\hline Factor 3 & 0.000023 & 0.000001 & 0.003586 & 0.000047 & 100.00 & 100.00 \\
\hline
\end{tabular}

\section{Additive genetic correlations and heritability of TDMYs}

Estimates of genetic correlations between TDMYs, ranged from -0.978 to 0.993 , -0.730 to 0.992 and -0.086 to 0.991 for the three lactations (Table 4 and Fig. 1,2 and 3 ), respectively. In the first and second pariteies, the estimates of genetic correlations were lower than those estimated by Van der Werf et al. (1998), Veerkamp and 
Thompson (1999) and Alnajjar (2001). Some of these estimates were negative. Liu et al. (2000) reported that using the biological lactation curves resulted in negative genetic correlations between the beginning and the end of lactation. Mean of genetic correlations between TDMYs were $0.149,0.568$ and 0.732 for the three lactations, respectively, i.e. increased from one lactation to the next. Alnajjar (2001) showed an opposite trend.

Estimates of heritability of TDMY (Table 4 and Fig. 4) increased from 0.030 for DIM 65 to 0.142 for DIM 185 then, decreased to 0.035 for DIM 275 in the first lactation. Heritability increased from 0.154 for DIM 65 to 0.215 for DIM 155 then decreased to 0.180 for DIM 215 in the second lactation. Heritability decreased from 0.486 for DIM 5 to 0.409 for DIM 125 then increased to 0.696 for DIM 305 in the third lactation. Estimates were generally low for all DIM in the first and second lactations. Low hertability observed here could be due to the relatively low production as Strabel and Misztal (1999) noticed that lower production, as the case in the present study, usually leads to lower heritability estimates. Veerkamp and Goddard (1998) reported heritability average around 0.13 for a herd with an average TDMY around $18 \mathrm{~kg}$ which is greater than that obtained in the present study. Low heritability could also be due to the small number of selected sires. The pattern of estimates of heritability agrees with that reported by Jamrozik et al. (1998) and Strabel and Misztal (1999) and Rekaya et al. (1999), high estimates at the beginning ( 0.118 and 0.090 at DIM 5 for the first and second lactation, respectively) followed by a decrease in following stage, and rising estimates toward the end of lactation. Generally, heritability estimates increased from the first to the second lactation and considerably increased in the third lactation.

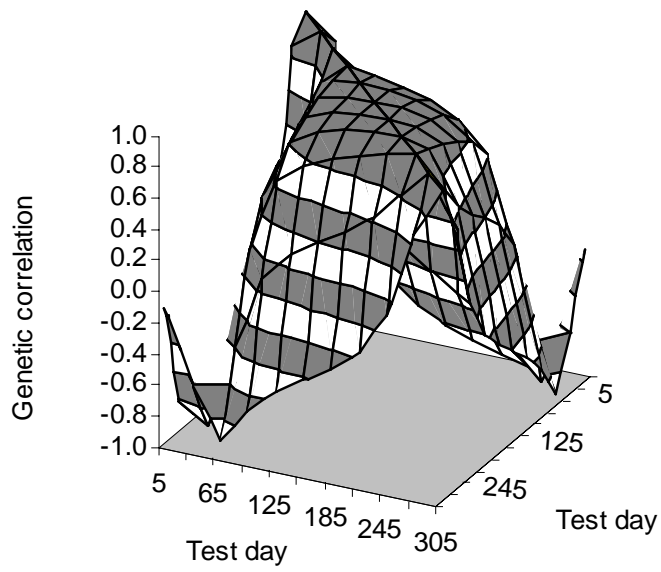

Fig. 1. Genetic correlations between TDMYs in the first lactation 


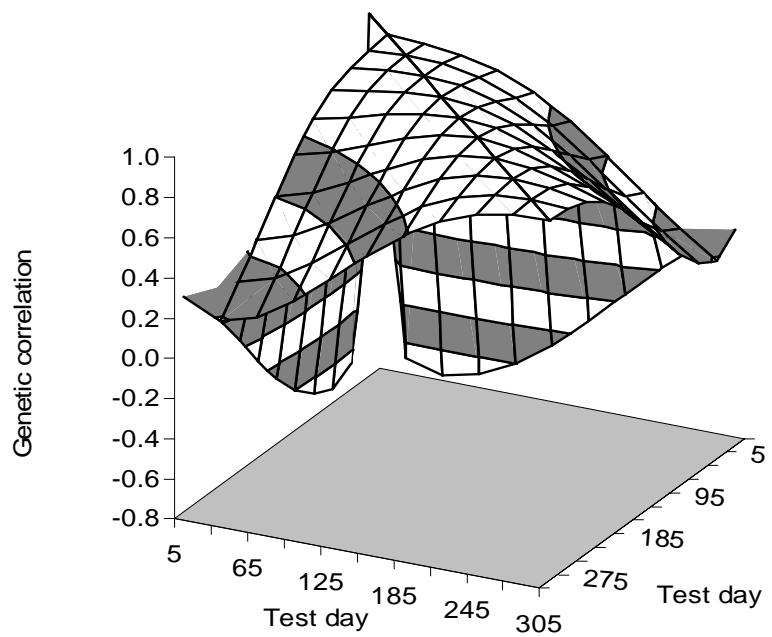

Fig. 2. Genetic correlations between TDMYs in the second lactation.

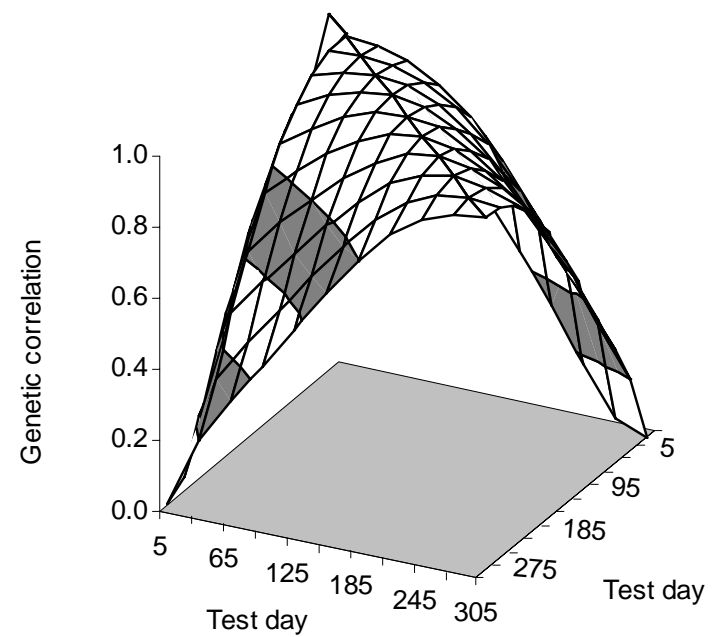

Fig. 3. Genetic correlations between TDMYs in the third lactation. 


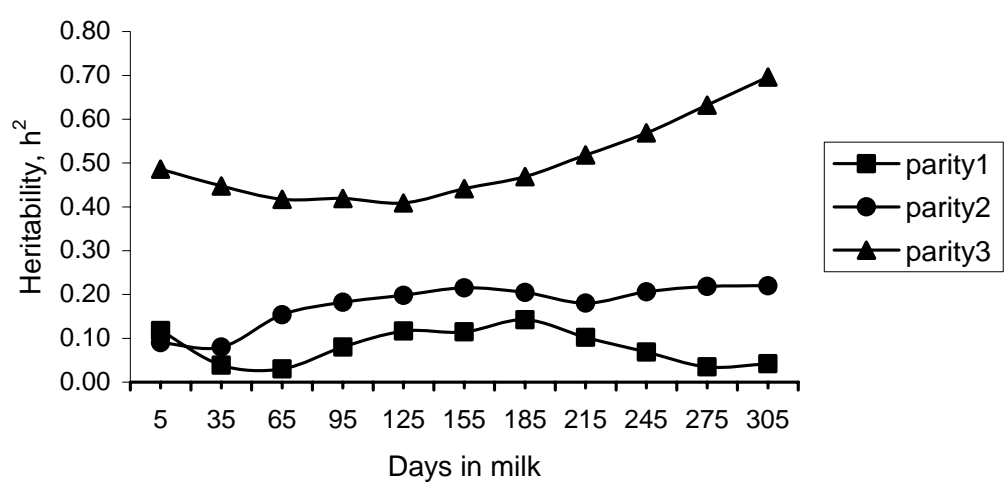

Fig. 4. Estimates of heritability for TDMYs in the first three lactations

\section{Phenotypic correlations between TDMYs}

Estimates of the phenotypic correlations ranged from 0.067 to $0.681,-0.110$ to 0.788 and -0.112 to 0.958 for the three lactations (Table 4 and Fig. 5, 6 and 7), respectively. Phenotypic correlations between adjacent TDMY were relatively high, ranging from 0.430 to $0.681,0.081$ to 0.788 and 0.737 to 0.957 for the three lactations, respectively, with the exception of DIM 5 with DIM 35 in the second lactation. As the interval between days increased, the estimates of phenotypic correlations generally decreased but with some irregularity involving the estimates of phenotypic correlations for DIM 5 with the others. White et al. (1999) showed that phenotypic correlations declined from 0.76 between adjacent lactation stages to 0.4 between initial and day 255 for the first lactation.

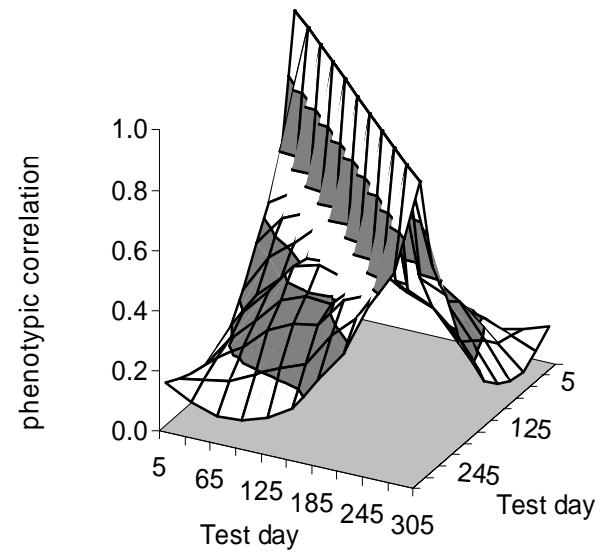

Fig. 5. Phenotypic correlations between TDMYs in the first lactation 


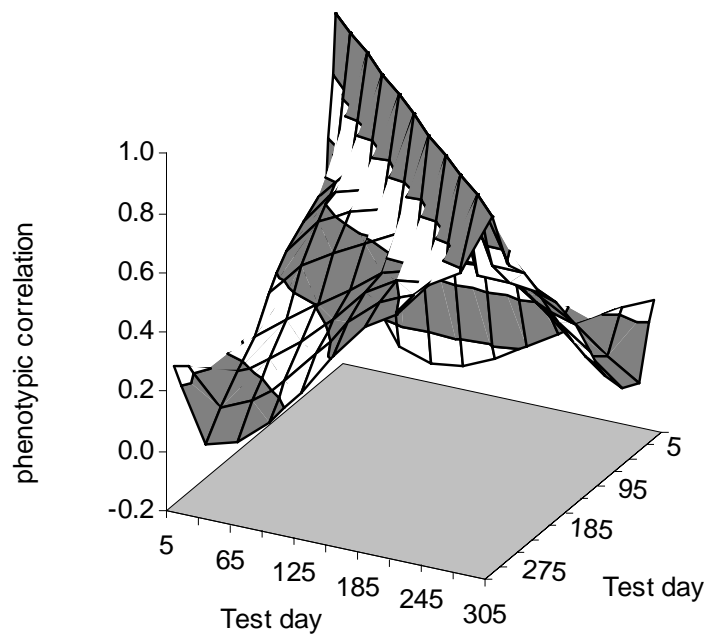

Fig. 6. Phenotypic correlations between TDMYs in the second lactation

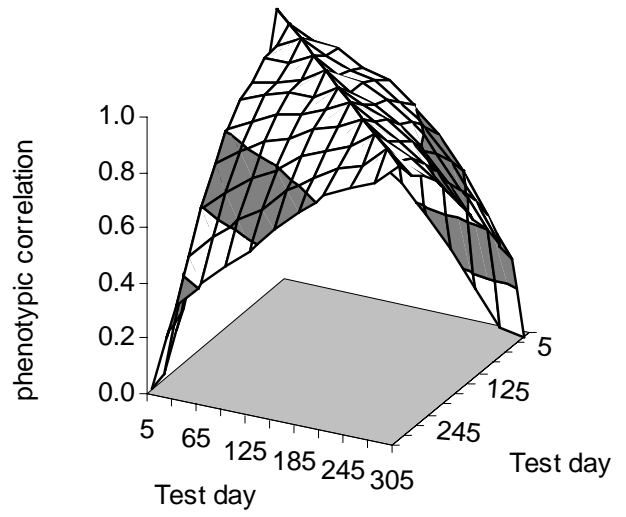

Fig. 7. Phenotypic correlations between TDMYs in the third lactation 
Table 4. Estimates of genetic correlations (below the diagonal), heritability (on the diagonal and bold) and phenotypic correlations (above the diagonal) for TDMY in the first three lactations

\begin{tabular}{|c|c|c|c|c|c|c|c|c|c|c|c|}
\hline \multicolumn{12}{|c|}{ First lactation } \\
\hline DIM & 5 & 35 & 65 & 95 & 125 & 155 & 185 & 215 & 245 & 275 & 305 \\
\hline 5 & 0.118 & 0.593 & 0.44 & 0.34 & & & & & 0.096 & 0.116 & \\
\hline 35 & & & & & & & & & & & \\
\hline 65 & -0.073 & 0.456 & $\mathbf{0 . 0 3 0}$ & 478 & 0.417 & .338 & .334 & 0.269 & .222 & 0.145 & .067 \\
\hline 95 & & & 860 & 0.080 & 0.494 & 0.421 & 0.434 & 0.359 & 0.299 & & .074 \\
\hline & & & & & & 0.43 & & & & & \\
\hline 55 & & & 0.638 & 0.9 & 0.9 & 0.115 & 0.434 & 0.386 & .353 & 261 & .15 \\
\hline & & & 543 & & 0.96 & 0.993 & 0.142 & 0.465 & 0.455 & 0.375 & 0.265 \\
\hline & & & & & 0.5 & 0.963 & & & & & \\
\hline & & & 156 & & 0.7 & 0.853 & & 0.962 & 0.069 & & \\
\hline & & & & & & 0.400 & & & & & \\
\hline & & & & & -0.529 & -0.417 & & & & & \\
\hline \multicolumn{12}{|c|}{ Second lactation } \\
\hline 5 & & & & & & & 0.017 & 0.082 & & & .263 \\
\hline 35 & & & & & 0.5 & & & & & & \\
\hline 65 & & 0.989 & & 0.6 & 0.6 & 0.573 & 63 & & 0.244 & 46 & 055 \\
\hline 95 & & 0.9 & & & 0.657 & 0.624 & & & 27 & 35 & \\
\hline & & & & & & & & & & & \\
\hline & & & & & 0.9 & 0.215 & & 59 & & & \\
\hline & & 0.742 & & 0.8 & & 0.981 & & 0.5 & & 75 & 31 \\
\hline & & & & & & & & & & & \\
\hline & & & & & & 0.839 & & 0. & 06 & 21 & \\
\hline & & .312 & 0.366 & 0.477 & 0.6 & 0.742 & 0.859 & 0.942 & 0.987 & .218 & 0.788 \\
\hline & & & & & 0.497 & 0.646 & & & 0.957 & .991 & .220 \\
\hline \multicolumn{12}{|c|}{$\begin{array}{l}\text { Third lactation } \\
\end{array}$} \\
\hline 5 & & & & & & & & & & & \\
\hline 35 & 0.877 & 0.448 & 0.958 & 0.948 & 0.902 & 0.875 & 306 & 0.719 & 0.598 & 0.463 & \\
\hline 65 & & & & & & & & & & & \\
\hline 95 & & & & & 0.946 & 0.944 & 0.901 & & 0.743 & & \\
\hline 125 & 0.671 & 0.918 & 0.963 & 0.990 & 0.409 & 0.944 & 0.915 & 0.869 & 0.788 & 0.689 & 0.575 \\
\hline & & & & & & 0.441 & & 0.924 & & & \\
\hline & & & & & & 0.986 & & 0.947 & 0.901 & 0.836 & 0.751 \\
\hline 215 & & 0.618 & & 0.800 & & 0.942 & 0.985 & 0.518 & 0.935 & 0.893 & 0.83 \\
\hline & & 0.478 & & & & 0.872 & 0.942 & 0.986 & 0.569 & 0.922 & 0.884 \\
\hline & 0.035 & 0.335 & & 0.566 & 0.677 & 0.784 & 0.877 & 0.947 & 0.988 & 0.632 & 0.921 \\
\hline 305 & -0.086 & 0.201 & 0.325 & 0.445 & & 0.689 & 0.801 & 0.893 & 0.956 & 0.990 & 0.696 \\
\hline
\end{tabular}




\section{CONCLUSIONS}

It was concluded that the IGF was suitable to describe the lactation curve in Holstein cattle under the conditions of this study. Low variance of coefficients of IGF could be due to incomplete pedigree information. The lactation curve of the present animals could be improved by improving management rather than genetics.

\section{ACKNOWLEDGMENTS}

Dr. Hamdy Elsayed, Professor of Animal Nutrition, Faculty of Agriculture, Ain Shams University, did his best to locate a data set suitable to this study among many farms that consult him. He generously spent his time in working out the logistics of obtaining the data. The authors are greatly indebted to him. Special thanks are due to Mr. Hamed El-Shewekh the manager of the Assiout farm for assisting in accessing the farm for providing the data during the farm visits. The authors are indebted to Dr. Emad Mousa, Assistant Professor of Animal Breeding, Faculty of Agriculture, Assiout University, for helping with the random regression technique in the early stage of the statistical analysis.

\section{REFERENCES}

Ali, T. E. and L. R. Schaeffer, 1987. Accounting for covariances among test day milk yields in dairy cows. Can. J. Anim. Sci. 67:637-644.

Alnajjar, K.A., 2001. A Study on Animal Genetic Evaluation in Dairy Cattle. pp 4668. Ph.D.Thesis, Fac. Agric., Ain Shams Univ, Cairo, Egypt.

Jamrozik, J., L.R. Schaeffer and J.C.M. Dekkers, 1997. Genetic evaluation of dairy cattle using test day yields and random regression model. J. Dairy Sci. 80:12171226.

Jamrozik, J., L.R. Schaeffer and J.C.M. Dekkers, 1996. Random regression model for production traits in Canadian Holstein. Proc. Open Session Interbull Annu. Mtg., Veldhoven, the Netherlands, June 23-24, Interbull Bull. Eval. Serv. Bull. 14:124134.

Jamrozik, J., L.R. Schaeffer and F. Grignola, 1998. Genetic parameters for production traits and somatic cell score of Canadian Holsteins with multiple trait random regression model. Proc. $6^{\text {th }}$ World Congr. Genet. Livest. Prod.. January 11-16, Armidale, New South Wales, Australia. XXIII:303-306.

Liu, Z., F. Reinhardt, and R. Reents, 2000. Estimating parameters of a random regression test day model for first three lactation milk production traits using the covariance function approach. INTERBULL Bulletin 25:74-80.

Meyer, K., 1998a. DFREML program version 3.1. CD-ROM, $6^{\text {th }}$ World Congr. Genet. Livest. Prod.. p. 33. January 11-16, Armidale, New South Wales, Australia.

Meyer, K., 1998b. Estimating covariance functions for longitudinal data using a random regression model. Genet. Sel. Evol. 30:221-240.

Meyer, K., 2002. A Program to estimate variance components for simple random regression models using Gibbs Sampling. USER NOTES. p. 37. 
Meyer, K., H.U. Graser and K. Hammond, 1989. Estimates of genetic parameters for first lactation test day production of Australian Black and White cows. Livest. Prod. Sci. 21:177-199.

Morrison, D.F., 1976. Multivariate Statistical Methods. pp: 247-253. McGraw-Hill Book Company New York.

Mrode, R.A., 1996. Linear Model for the Prediction of Animal Breeding Values. pp: 162-163. CAB International Wallingford Oxon ox10 8DE,UK.

Olori, V. E.,W.G. Hill, B.J. McGuirk and S. Brotherstone, 1999. Estimating variance components for test day milk records by restricted maximum likelihood with a random regression animal model. Livest. Prod. Sci. 61:53-63.

Pool, M.H., and T.H.E. Meuwissen, 2000. Reduced rank covariance functions in multi-trait random regression test day models. $51^{\text {th }}$ Annual Meeting of the European Association for Animal Production (EAAP), August 21-24 Den Hague, The Netherlands, p:6.

Ptak, E., and L.R. Schaeffer, 1993. Use of test day yields for genetic evaluation in dairy sires and cows. Livest. Prod. Sci. 34:23-34.

Reents, R., and L. Dopp, 1996. Genetic evaluation for dairy production traits with a test day model for multiple lactations. INTERBULL Open Mtg., Veldhoven, The Netherlands. in Bull. 14. Int. Bull Eva., Uppsala, Sweden, 113-117.

Rekaya, R., M. J. Carabanõ, and M.A. Toro, 1999. Use of test day yields for the genetic evaluation of production traits in Holstein- Friesian cattle. Livest. Prod. Sci. 57:203-217.

Schaeffer, L. R., and J. C. M. Dekkers, 1994. Random regressions in animal models for test day production in dairy cattle. Proc. $5^{\text {th }}$ World Congr. on Genetics Appl. Livest. Prod. August 7-12, Canada, Vol. Guelph, 18:443-446.

Searle, S.R., 1966. Matrix Algebra for the Biological Sciences. John Wiley \& Sons, Inc., New York. pp: 296.

Strabel, T. and I. Misztal, 1999. Genetic parameters for first and second milk yields of Polish Black and White cattle with random regression test-day models. J. Dairy Sci. 82:2805-2810.

Van der Werf, J.H.J., M.E. Goddard and K. Meyer, 1998. The use of covariance functions and random regressions for genetic evaluation of milk production based on test day records. J. Dairy Sci. 81:3300-3308.

Veerkamp, R.F., and M.E. Goodard, 1998. Covariance functions across herd production levels for test day records on milk, fat, and protein yields. J. Dairy Sci. 81:1690-1701.

Veerkamp, R. F., and R. Thompson, 1999. A covariance function for feed intake, live weight, and milk yield estimated using a random regression model. J. Dairy Sci. 82:1565-1573.

White, I.M.S., R. Thompson, and S. Brotherstone, 1999. Genetic and environmental smoothing of lactation curves with cubic splines. J. Dairy Sci. 82:632-638.

Wilmink, J.B.M., 1987. Adjustment of test-day milk, fat and protein yield for age, season and stage of lactation. Livest. Prod. Sci. 16:335-348.

Wood, P.D.P., 1967. Algebraic model of the lactation curve in cattle. Nature (Lond.) 216:164-165. 
تقدير المعالم الوراثية لإنتاج اللبن في أول ثلاثة مواسم لأبقار الهولشتين باستخدام نموذج الإنحدار العثوائى المعى

نيفين جمال، منال السيد²، صلاح جلال2

وحدة الحساب العلمس، كلية الزراعة، جامعة عين شسس، 2- قسم الإنتاج الحيوانس، كلية الزراعة، جامعة

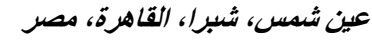

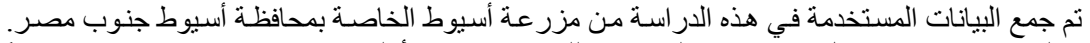

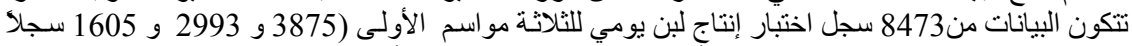

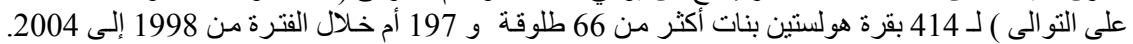

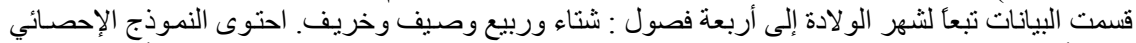

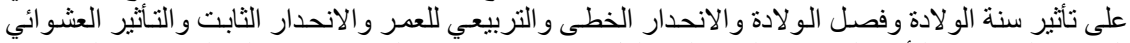

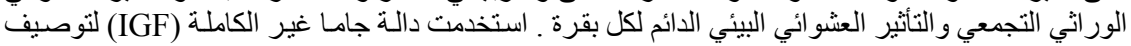

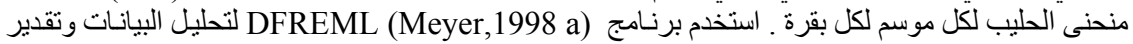

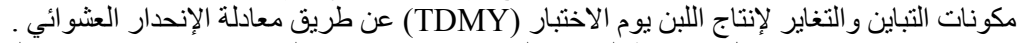

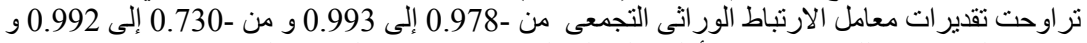

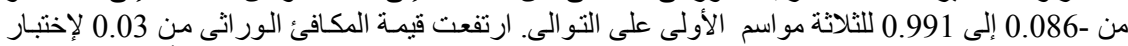

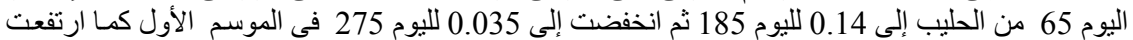

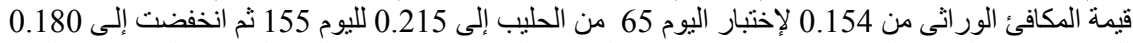

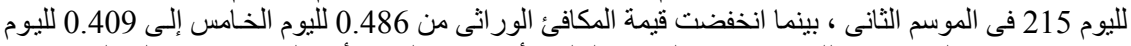

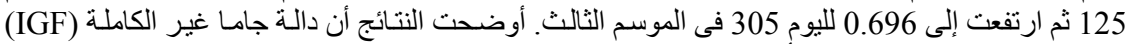

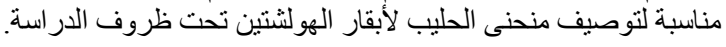

